DE

M E D I C I N A

T R O P I C A L

$\mathrm{DE}$

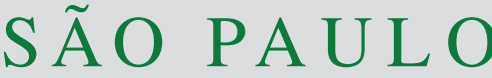

JOURNAL OF THE SÃO PAULO INSTITUTE OF TROPICAL MEDICINE

'Universidade de São Paulo, Faculdade de Medicina, Departamento de Moléstias Infecciosas e Parasitárias, São Paulo, São Paulo, Brazil

Correspondence to: Vivian lida AvelinoSilva

Universidade de São Paulo, Faculdade de Medicina, Departamento de Moléstias Infecciosas e Parasitárias, Av. Dr. Enéas de Carvalho Aguiar, 470, CEP 05403-000, São Paulo, SP, Brazil

Tel: +55 1130617347

E-mail: viviansilva87@gmail.com

Received: 2 September 2019

Accepted: 6 January 2020

\section{Access and adherence to isoniazid preventive therapy and occurrence of active TB in a cohort of people living with HIV: a retrospective cohort study in Sao Paulo, Brazil}

\author{
Camila Melo Picone ${ }^{\circledR 1}$, Angela Carvalho Freitas ${ }^{1}$, Eliana B. Gutierrez¹, Vivian \\ lida Avelino-Silva ${ }^{(1)}$
}

\section{ABSTRACT}

Tuberculosis (TB) is still a leading cause of morbidity and mortality among people living with HIV (PLHIV). The diagnosis of latent TB is required for the implementation of prophylactic therapy with isoniazid (PTI). However, low access to diagnosis of latent TB and non-adherence to PTI may hinder potential benefits of this essential intervention. In this study, we addressed the access and adherence to PTI in a cohort of PLHIV with positive tuberculin skin test (TST) in a reference HIV clinic in Sao Paulo, Brazil. We have also analyzed the occurrence of active TB over a median of 131 months after a positive TST among study participants. Our findings revealed that $88.3 \%$ of the 238 TST-positive patients had access to PTI, and 196 (93.3\%) of those with access adhered to PTI. Active tuberculosis was diagnosed in three of the 196 TST-positive patients who adhered to PTI $(1.5 \%$; $95 \%$ confidence interval [CI] 0.3-4.4\%), whereas seven cases were detected among 42 patients without access or who did not adhere to PTI (16.6\%; 95\% CI 7.0-31.3\%). The apparent beneficial effect of PTI in our cohort is consistent with previous studies including PLHIV, and highlights the importance of reliably delivering each of the steps between screening for latent TB and provision of PTI.

KEYWORDS: Active tuberculosis. Adherence. HIV. Isoniazid preventive therapy. Prophylactic therapy. Tuberculin skin test. Tuberculin test. Tuberculosis.

\section{INTRODUCTION}

According to the World Health Organization (WHO) Global tuberculosis report 2019, tuberculosis (TB) is the leading cause of death from a single infectious agent, with estimated 1.2 million deaths among HIV-negative people and additional 251,000 deaths among people living with HIV (PLHIV) in 2018 alone. HIV infection is a consistent risk factor for active TB, and PLHIV represent $8.6 \%$ of all TB cases ${ }^{1}$.

Brazil is one of the 30 countries with high TB burden listed by WHO, which collectively represent $87 \%$ of the global occurrence of the disease. In 2015 , 69,000 TB cases and 4,500 TB-related deaths were registered in Brazil, of which 1,700 occurred among PLHIV. Sao Paulo State recorded more than 17,000 TB cases in the same year, of which 1,474 occurred among PLHIV ${ }^{2}$.

Asymptomatic or latent infection with Mycobacterium tuberculosis precedes the development of active TB. Prophylactic therapy with isoniazid (PTI) is a safe and effective intervention to prevent the development of active TB among patients with latent infection ${ }^{3,4}$. A positive tuberculin skin test (TST) and/or positive interferon- $\gamma$ 
release assay are the currently available tools for latent TB diagnosis in clinical settings ${ }^{5}$.

Although previous studies have documented the beneficial impact of PTI among PLHIV ${ }^{6-10}$, barriers in the diagnosis of latent TB infection, in the implementation of PTI, and non-adherence to PTI may hinder potential benefits of this essential intervention ${ }^{11-14}$.

In this retrospective cohort study, we addressed the access and adherence to PTI in a cohort of PLHIV with positive TST. We have also analyzed the occurrence of active tuberculosis over a median 131 months after a positive TST, according to PTI uptake among study participants.

\section{METHODS}

Around 3,500 adult patients attending the HIV outpatient clinic at Hospital das Clinicas da Faculdade de Medicina da Universidade de Sao Paulo were screened to participate in the study.

We included all patients undergoing a TST between February 2005 and December 2009 as part of routine care. Local guidelines recommend yearly TST to all PLHIV without a previously positive TST and without previous or current active $\mathrm{TB}^{15}$, regardless of CD4+ counts. The test was performed with an intradermal injection of $0.1 \mathrm{~mL}$ of the purified protein derivative (PPD-Rt-23, Statens Serum Institut, Copenhagen $)^{16}$ on the anterior part of the left arm. A trained nurse measured the local reaction $72 \mathrm{~h}$ after TST administration ${ }^{17-19}$. All patients with reactions $\geq 5 \mathrm{~mm}$ were considered to have a positive TST result.

We addressed the access to PTI among patients who had a positive TST using isoniazid prescription records as well as medical chart records of isoniazid use. PTI regimen prescribed in our institution consisted of $300 \mathrm{mg}$ of isoniazid daily, for 180 days. Adherence to PTI was characterized using pharmacy records of isoniazid monthly dispensations and data from medical charts. Directly observed treatment is not used for PTI in our clinic. PTI was considered complete for the all patients receiving treatment for at least 180 consecutive days.

Retrospective follow-up of clinical outcomes was performed for a median of 131 months (range 107-154) to identify cases of active TB. We used data from medical charts, pharmacy records for dispensation of active TB regimen, laboratory results, histopathology and radiology reports, and the TB surveillance system from Sao Paulo State; the adjudication of active TB was carried out by two independent infectious diseases specialists. Different data sources were linked using either the unique identifier assigned for each patient in the hospital system, or the patient's name and date of birth in the case of the TB surveillance system.
We used descriptive statistics to present patients' characteristics. To compare patients with or without access to PTI we used chi-squared test for categorical variables and the Wilcoxon Rank-Sum test for numerical variables. For all analyses, we used Stata 15.1 (StataCorp. College Station, TX: StataCorp LP) with a 0.05 significance level.

The Ethics Committee of Hospital das Clinicas da Faculdade de Medicina da Universidade de Sao Paulo approved the study (approval $\mathrm{N}^{\circ} 2.624 .521$ ) with exemption of the informed consent due to the retrospective design and data collection of the study. All the participants' identifiable information were maintained confidential throughout the study.

\section{RESULTS}

Between February 2005 and December 2009, 3,260 TST were performed in 1,983 patients. Of those, $72 \mathrm{~h}$ reaction measurement was carried out for 2,878 tests, with an overall percentage of missing TST measurement appointment of $11.7 \%$. TST was positive $(\geq 5 \mathrm{~mm})$ in 246 participants, representing $8.5 \%$ of the patients with available TST measurement. After the exclusion of six patients lost to follow-up, one patient transferred to another clinic and one patient who died due to TB-unrelated causes, 238 TST-positive patients were retrieved for evaluation of PTI access and adherence.

\section{Access and adherence to PTI}

Demographic and clinical characteristics of the 238 TST-positive patients according to access to PTI are shown in Table 1. Access to PTI was identified in 210 of 238 TST-positive patients (88.2\%). Groups were similar in regard to sex, age, race, education, proportion under antiretroviral treatment, proportion with undetectable HIV viral load and regarding CD4+ lymphocyte counts; however, patients with access to PTI had higher median CD4+ nadir ( 215 vs. $153, \mathrm{p}=0.031$ ) and were more likely to have a TST $\geq 10 \mathrm{~mm}$ ( 71 vs. $32 \%, \mathrm{p}<0.001)$.

Among the 28 TST-positive patients for whom no PTI was prescribed (11.8\%), 21 (75.0\%) had no clear justification for the missed prescription in medical charts. The remaining seven TST-positive patients without access to PTI had medical chart notes listing depression (two patients) and chronic liver disease (three patients) as reasons for the absence of PTI; in two additional cases the healthcare provider questioned the accuracy of the TST result.

Among the 210 TST-positive patients who had access to PTI, 196 (93.3\%) were considered adherent to PTI (Figure 1). Of the 14 patients who were non-adherent, eight 
Table 1 - Demographic and clinical characteristics of the 238 tuberculin skin test-positive patients, according to access to prophylactic therapy with isoniazid.

\begin{tabular}{|c|c|c|c|}
\hline & \multicolumn{2}{|c|}{ Access to prophylactic isoniazid } & \multirow[b]{2}{*}{$\mathrm{p}$-value } \\
\hline & $\begin{array}{c}\text { Yes } \\
\mathrm{N}=210\end{array}$ & $\begin{array}{c}\text { No } \\
\mathrm{N}=28\end{array}$ & \\
\hline Male sex (\%) & $147(70.0)$ & $21(75.0)$ & 0.585 \\
\hline Age at TST (years) & 42 & 46 & 0.196 \\
\hline \multicolumn{4}{|l|}{ Ethnicity (\%) } \\
\hline White/Caucasian & $166(79.0)$ & $25(89.3)$ & \\
\hline Non-white/caucasian & $40(19.0)$ & $3(10.7)$ & 0.434 \\
\hline Not informed & $4(1.9)$ & - & \\
\hline \multicolumn{4}{|l|}{ Education (years) } \\
\hline 0 & $3(1.4)$ & 0 & \\
\hline$\leq 7$ & $22(10.5)$ & $2(7.1)$ & \\
\hline $8-11$ & $134(63.8)$ & $20(71.4)$ & 0.864 \\
\hline$\geq 12$ & $29(13.8)$ & $5(17.9)$ & \\
\hline Missing & $22(10.5)$ & $1(3.6)$ & \\
\hline Under antiretroviral therapy (\%) & $185(88.1)$ & $26(92.9)$ & 0.455 \\
\hline CD4+ count at TST (cells $/ \mathrm{mm}^{3}$ ) & 653 & 514 & 0.140 \\
\hline Nadir CD4+ count (cells/mm³) & 215 & 153 & 0.031 \\
\hline Undetectable HIV viral load (\%) & $150(71.4)$ & $23(82.1)$ & 0.359 \\
\hline Coexisting comorbidity (\%) & $106(50.5)$ & $12(42.9)$ & 0.449 \\
\hline Concurrent medications (\%) & $110(52.4)$ & $18(64.3)$ & 0.235 \\
\hline Tuberculin skin test $\geq 10 \mathrm{~mm}(\%)$ & $150(71.4)$ & $9(32.1)$ & $<0.001$ \\
\hline
\end{tabular}

Numeric variables are presented as medians. Undetectable HIV viral load is defined as $<400 \mathrm{copies} / \mathrm{mL}$.

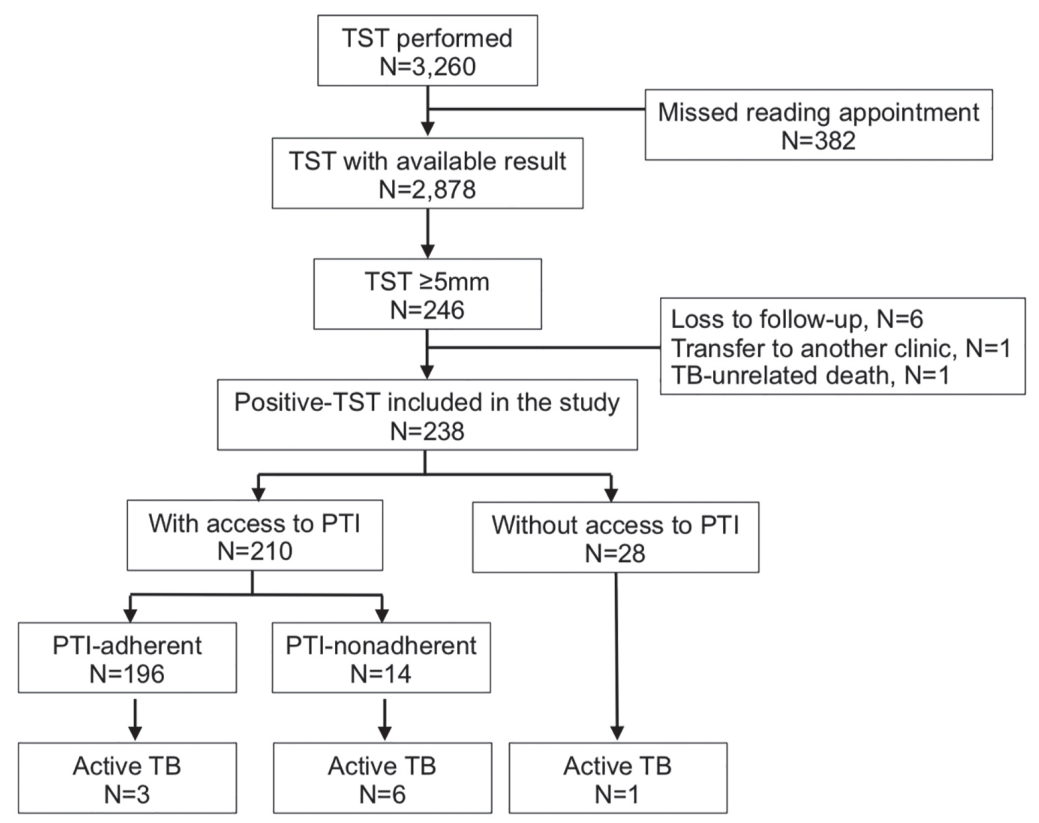

Figure 1 - Overview of the study participants and their outcomes.

remained free of active TB during the follow-up period. The median time on PTI was 75 days $(41.7 \%$ of total PTI treatment) for the eight non-adherent patients without active TB. Information on the reasons for PTI withdrawal was available for two patients: one reported gastrointestinal side-effects and the other simply refused PTI.

\section{Active TB diagnosis during follow-up}

We detected active TB in three of the 196 PTI-adherent patients $(1.5 \%)$ after a median follow-up of 114 months. In contrast, six of the 14 patients who were non-adherent to PTI developed active TB after a median follow-up of 
106 months post positive TST (42.9\%). Of the 28 patients who failed to access PTI, one (3.6\%) developed active TB after 59 months.

A complete description of the access and adherence to PTI, as well as active TB development is presented in Figure 1, and a detailed description of active TB cases is provided in Table 2. All patients with active TB were under antiretroviral therapy, although only six of them had undetectable HIV viral load $(<400$ copies/mL). In six patients, CD4 count was $<350 / \mathrm{mm}^{3}$. Respiratory tract was the single site of TB in only three cases; disseminated TB, affecting two or more organs was diagnosed in five cases; TB restricted to eyes and lymph nodes accounted for one case each.

All except for one patient had access to PTI, however non-adherence was detected in six cases, including four patients with CD4 count $<350 / \mathrm{mm}^{3}$. Among the three patients adherent to PTI, two had very low CD4+ counts (147 and 42 cells $/ \mathrm{mm}^{3}$ ), which may have predisposed to active TB despite PTI. Poor retention in TB treatment was observed for two patients. One patient with pulmonary and meningeal TB died three months after TB diagnosis, and the remaining seven patients were considered cured after TB treatment.
Effect of prophylactic therapy with isoniazid on the development of active tuberculosis among PLHIV with a positive TST

Overall, only three TB cases were diagnosed among 196 TST-positive patients who adhered to PTI (1.5\%; 95\% confidence interval [CI] 0.3-4.4\%), whereas seven cases were detected among 42 patients without access or non-adherent to PTI $(16.6 \%$; $95 \%$ CI $7.0-31.3 \%$; $<<0.001)$.

\section{DISCUSSION}

In this retrospective cohort, we showed that more than $10 \%$ of PLHIV who had positive TST as part of routine care, failed to receive PTI in an academic HIV outpatient clinic in Sao Paulo, Brazil. Interestingly, participants with access to PTI had higher median CD4+ nadir (215 vs. 153, $\mathrm{p}=0.031$ ). Access to PTI may have been facilitated for patients with better overall access to healthcare, who underwent HIV testing earlier in the course of infection. We have also found that participants with access to PTI were more likely to have a TST $\geq 10 \mathrm{~mm}$ ( 71 vs. $32 \%, \mathrm{p}<0.001)$. It is plausible that providers were more persuaded to prescribe PTI for patients

Table 2 - Detailed description of the 10 active tuberculosis cases identified in the cohort.

\begin{tabular}{|c|c|c|c|c|c|c|c|c|c|c|c|}
\hline Case & Age, Sex & Ethnicity & ART & $\begin{array}{c}\text { CD4+ } \\
\text { count } \\
\left.\text { (cells } / \mathrm{mm}^{3}\right) \\
\end{array}$ & $\begin{array}{l}\text { Undetectable } \\
\text { HIV viral load } \\
\text { under ART }\end{array}$ & $\begin{array}{l}\text { TST } \\
(\mathrm{mm})\end{array}$ & $\begin{array}{c}\text { PTI } \\
\text { access }\end{array}$ & $\begin{array}{c}\text { PTI } \\
\text { adherence }\end{array}$ & $\begin{array}{l}\text { Time } \\
\text { on PTI } \\
\text { (days) }\end{array}$ & $\begin{array}{c}\text { Time to TB } \\
\text { (months) }\end{array}$ & $\begin{array}{l}\text { TB presentation } \\
\text { and clinical } \\
\text { outcome }\end{array}$ \\
\hline 1 & $41, \mathrm{~F}$ & Mixed & Yes & 511 & Yes & 15 & Yes & Yes & 180 & 16 & $\begin{array}{c}\text { Pulmonary and urinary } \\
\text { tract TB, treatment } \\
\text { completed; cure }\end{array}$ \\
\hline 2 & $49, M$ & Caucasian & Yes & 42 & No & 9 & Yes & Yes & 180 & 114 & $\begin{array}{c}\text { Pulmonary and bone TB, } \\
\text { poor retention, did not } \\
\text { complete treatment }\end{array}$ \\
\hline 3 & $38, F$ & Caucasian & Yes & 147 & Yes & 19 & Yes & Yes & 180 & 132 & $\begin{array}{l}\text { Pulmonary TB, treatment } \\
\text { completed; cure }\end{array}$ \\
\hline 4 & $58, \mathrm{M}$ & Caucasian & Yes & 271 & No & 6 & Yes & No & 90 & 23 & $\begin{array}{l}\text { Pulmonary TB, treatment } \\
\text { completed; cure }\end{array}$ \\
\hline 5 & $25, M$ & Caucasian & Yes & 119 & No & 18 & Yes & No & 90 & 53 & $\begin{array}{l}\text { Lymph node TB, poor } \\
\text { retention, did not } \\
\text { complete treatment }\end{array}$ \\
\hline 6 & $32, \mathrm{~F}$ & Caucasian & Yes & 609 & Yes & 21 & Yes & No & 30 & 95 & $\begin{array}{c}\text { Meningeal and urinary } \\
\text { tract TB, treatment } \\
\text { completed; cure }\end{array}$ \\
\hline 7 & $24, F$ & Caucasian & Yes & 339 & Yes & 20 & Yes & No & 90 & 117 & $\begin{array}{c}\text { Pulmonary and } \\
\text { meningeal TB, treatment } \\
\text { completed; death }\end{array}$ \\
\hline 8 & $71, \mathrm{M}$ & Black & Yes & 37 & No & 9 & Yes & No & 60 & 121 & $\begin{array}{l}\text { Pulmonary TB, treatment } \\
\text { completed; cure }\end{array}$ \\
\hline 9 & $42, \mathrm{M}$ & Caucasian & Yes & 447 & Yes & 19 & Yes & No & 150 & 129 & $\begin{array}{l}\text { Miliary TB, treatment } \\
\text { completed; cure }\end{array}$ \\
\hline 10 & $57, \mathrm{M}$ & Black & Yes & 550 & Yes & 15 & No & $\begin{array}{c}\text { Not } \\
\text { applicable }\end{array}$ & 0 & 59 & $\begin{array}{l}\text { Ocular TB, treatment } \\
\text { completed; cure }\end{array}$ \\
\hline
\end{tabular}

$\mathrm{M}=$ male; $\mathrm{F}=$ female; $\mathrm{ART}$ = antiretroviral therapy; $\mathrm{TST}$ = tuberculin skin test; $\mathrm{PTI}=$ prophylactic therapy with isoniazid; $\mathrm{TB}=$ tuberculosis; $\mathrm{HIV}$ viral load was considered undetectable when $<400$ copies $/ \mathrm{mL}$ 
with a TST $\geq 10 \mathrm{~mm}$ given that lower measurements might be due to previous BCG vaccination, routinely performed in Brazil.

Adherence to PTI was high (93.3\%) among patients who received PTI. Although active TB was diagnosed in only 10 cases (4.2\%) after a median follow-up of 105 months, patients with access and adherence to PTI had lower occurrence of active TB when compared to patients without access or non-adherent to PTI (1.5\%, 95\% CI 0.3-4.4 vs. $16.6 \%, 95 \%$ CI 7.0-31.3, respectively).

Yearly screening of latent TB infection is recommended by the Brazilian Ministry of Health ${ }^{20,21}$, and PTI is recommended for all PLHIV with a TST $\geq 5 \mathrm{~mm}$. In settings with scarcity of TST, PTI is recommended for all PLHIV with CD4+ counts $<350$, those with virological failure or who are not on antiretroviral therapy, and those with increased risk based on epidemiological characteristics ${ }^{15,22}$. It is also important to mention that antiretroviral treatment is available in the Brazilian public healthcare system for all PLHIV, and HIV clinics offer joint, free of charge care for patients with latent or active TB. The Brazilian Ministry of Health issues comprehensive and updated guidelines for TB management among PLHIV ${ }^{22}$.

TST has important limitations. The yearly frequency of TST performance may fail to detect TB exposure between the measurements. Moreover, the measurement of TST result requires an additional consultation at the healthcare service, increasing the cost, complexity, and incurring in a higher percentage of missing results. In our cohort, $382(11.7 \%)$ of 3,260 TST performed missed the return visit and could not be included in the study ${ }^{23,24}$. Finally, the shortage of supplies required to perform TST has been documented in several states of Brazil and have also been reported in a few studies ${ }^{25-27}$. One alternative diagnostic test to identify latent TB is the interferon- $\gamma$ release assay, which detects the patient's lymphocyte response to TB-specific antigens using a single blood sample. Cost-effectiveness studies are currently underway in Brazil to investigate the feasibility of implementation of this test.

Our study had a few limitations. Only 1,983 patients underwent TST during the study period. The remaining 1,500 PLHIV regularly followed in our clinic failed to perform TST because: i) They had a positive test in the past, with or without prior PTI; ii) They had previous or current TB; iii) They had contraindications to PTI; iv) The healthcare provider failed to request the test; v) The patient failed to perform the test despite a medical indication.

Considering that the nursing providers in our institution routinely screen patients who are eligible for TST, we believe that failure of TST requesting was a rare event.
In addition, most patients have been followed for several years and, in an endemic country such as Brazil, are likely to have had a positive TST in the past.

One strength of our study is the use of prospectively collected data from a large reference clinic in the Sao Paulo State, allowing the linkage of data from different sources.

Previous studies conducted in Africa and in Brazil showed lower rates of access and adherence to PTI compared to our study ${ }^{12,28,29}$. In the study conducted by Saraceni et al..$^{30}$ in Rio de Janeiro, only 17 of 67 eligible PLHIV (25.4\%) had access to PTI; adherence to PTI was 53\% among Brazilian patients enrolled in general healthcare facilities ${ }^{31}$. Santos et al. ${ }^{32}$ showed that 53 out of 66 eligible PLHIV had access to PTI (80.3\%), but only 26 completed PTI (49.1\%). In our own institution, a cross-sectional study conducted in 2005 showed that only 59\% of eligible PLHIV had access to TST and only $55 \%$ of eligible patients had access to PTI ${ }^{11}$. This study prompted the initiation of a training and education program along with the establishment of routine screening of patients during every pre-consultation evaluation and consequently, the access and adherence to PTI have increased substantially in our institution.

Although the overall access and adherence to PTI were high in our cohort (88.2 and $93.3 \%$ respectively), only seven out of 28 patients ( $25 \%$ ) included in our study who failed to access PTI had medical charts notes describing the reason why PTI was not prescribed. This highlights the need for continuous training among healthcare providers, even in an academic institution.

Other studies including PLHIV have addressed predictors of adherence to PTI among PLHIV. In a study conducted in urban Malawi, Thindwa et al. ${ }^{33}$ showed that lower CD4+ counts, PTI side effects and HIV WHO stages 3 and 4 were associated with lower adherence to PTI. In Brazil, treatment intolerance and distance to the healthcare facility were identified as predictors of non-adherence to PTI among household contacts of TB patients ${ }^{34}$. In our study, since most patients were adherent to PTI, we could not explore the risk factors for PTI non-adherence.

The apparent beneficial effect of PTI in our cohort is consistent with previous studies including PLHIV and underscores the importance of a reliable delivery of each step between screening of latent TB and provision of PTI. In a recent review, Alsdurf et al. ${ }^{35}$ described significant flaws at several steps in the cascade of latent TB diagnosis and treatment, including completion of testing, medical evaluation after testing, referral for treatment and completion of treatment. The high access and adherence to PTI observed in our clinic was achieved after education and treatment interventions that must be periodically repeated so as to attain the highest impact. However, $11.7 \%$ of 
our patients missed the TST measurement appointment, revealing potential pitfalls in the cascade of latent TB diagnosis and treatment. Strategies to further improve access and adherence to PTI have been explored by several authors, including shorter duration regimens, use of digital technologies to improve adherence and retention in care, use of simplified treatment regimens or use of regimens with better tolerance ${ }^{36-38}$. In addition, access to PTI could be improved with the implementation of the interferon- $\gamma$ release assay testing in settings with scarcity of TST or whenever an additional visit to the clinic to assess the TST result is not feasible ${ }^{39}$. The burden of TB-associated morbidity and mortality among PLHIV highlights the need for a comprehensive management of latent TB diagnosis and treatment.

\section{REFERENCES}

1. World Health Organization. Global tuberculosis report 2019. Geneva: WHO; 2019.

2. São Paulo. Secretaria de Estado da Saúde. Coordenadoria de Controle de Doenças. Centro de Vigilância Epidemiológica "Prof. Alexandre Vranjac". Programa de Controle da Tuberculose do Estado de São Paulo. Plano estadual pela eliminação da tuberculose: 2018 a 2021. [cited 2020 Jan 7]. Available from: http://www.saude.sp.gov.br/resources/cvecentro-de-vigilancia-epidemiologica/areas-de-vigilancia/ tuberculose/doc/tb17_plano_eliminacao.pdf

3. Conde MB, Melo FA, Marques AM, Cardoso NC, Pinheiro VG, Dalcin PT, et al. III Diretrizes para Tuberculose da Sociedade Brasileira de Pneumologia e Tisiologia. J Bras Pneumol. 2009;35:1018-48.

4. Zenner D, Beer N, Harris RJ, Lipman MC, Stagg HR, van der Werf MJ. Treatment of latent tuberculosis infection: an updated network meta-analysis. Ann Intern Med. 2017;167:248-55.

5. World Health Organization. Latent tuberculosis infection: updated and consolidated guidelines for programmatic management. Geneva: WHO; 2018. [cited 2020 Jan 7]. Available from: https://apps.who.int/iris/bitstream/hand le/10665/260233/9789241550239-eng.pdf

6. Ayele HT, Mourik MS, Debray TP, Bonten MJ. Isoniazid prophylactic therapy for the prevention of tuberculosis in HIV infected adults: a systematic review and meta-analysis of randomized trials. PLoS One. 2015;10:e0142290.

7. Danel C, Moh R, Gabillard D, Badje A, Le Carrou J, Ouassa T, et al. A trial of early antiretrovirals and isoniazid preventive therapy in Africa. N Engl J Med. 2015;373:808-22.

8. Bruins WS, van Leth F. Effect of secondary preventive therapy on recurrence of tuberculosis in HIV-infected individuals: a systematic review. Infect Dis (Lond). 2017;49:161-9.

9. Golub JE, Cohn S, Saraceni V, Cavalcante SC, Pacheco AG,
Moulton LH, et al. Long-term protection from isoniazid preventive therapy for tuberculosis in HIV-infected patients in a medium-burden tuberculosis setting: the TB/HIV in Rio (THRio) study. Clin Infect Dis. 2015;60:639-45.

10. Briggs MA, Emerson C, Modi S, Taylor NK, Date A. Use of isoniazid preventive therapy for tuberculosis prophylaxis among people living with HIV/AIDS: a review of the literature. J Acquir Immune Defic Syndr. 2015;68 Suppl 3:S297-305.

11. Gutierrez EB, Gomes V, Picone CM, Suga H, Atomiya AN. Active tuberculosis and Mycobacterium tuberculosis latent infection in patients with HIV/AIDS. HIV Med. 2009;10:564-72.

12. Durovni B, Cavalcante SC, Saraceni V, Vellozo V, Israel G, King BS, et al. The implementation of isoniazid preventive therapy in HIV clinics: the experience from the TB/HIV in Rio (THRio) study. AIDS. 2010;24 Suppl 5:S49-56.

13. Eldred LJ, Churchyard G, Durovni B, Godfrey-Faussett P, Grant $\mathrm{AD}$, Getahun $\mathrm{H}$, et al. Isoniazid preventive therapy for HIVinfected people: evidence to support implementation. AIDS. 2010;24 Suppl 5:S1-3.

14. Durovni B, Saraceni V, Moulton LH, Pacheco AG, Cavalcante SC, King BS, et al. Effect of improved tuberculosis screening and isoniazid preventive therapy on incidence of tuberculosis and death in patients with HIV in clinics in Rio de Janeiro, Brazil: a stepped wedge, cluster-randomised trial. Lancet Infect Dis. 2013;13:852-8.

15. Brasil. Ministério da Saúde. Secretaria de Vigilância em Saúde. Departamento de Vigilância, Prevenção e Controle das Infecções Sexualmente Transmissíveis, do HIV/AIDS e das Hepatites Virais. Protocolo clínico e diretrizes terapêuticas para manejo da infecção pelo HIV em adultos. Brasília: Ministério da Saúde; 2018. [cited 2020 Jan 7]. Available from: http://www. aids.gov.br/pt-br/pub/2013/protocolo-clinico-e-diretrizesterapeuticas-para-manejo-da-infeccao-pelo-hiv-em-adultos

16. Magnusson M, Bentzon MW. Preparation of purified tuberculin RT 23. Bull World Health Organ. 1958;19:829-43.

17. Brasil. Ministério da Saúde. Secretaria de Vigilância em Saúde. Departamento de Vigilância Epidemiológica. Tratamento diretamente observado (TDO) da tuberculose na atenção básica: protocolo de enfermagem. Brasília: Ministério da Saúde; 2011. [cited 2020 Jan 7]. Available from: http:// bvsms.saude.gov.br/bvs/publicacoes/tratamento_diretamente_ observado_tuberculose.pdf

18. Carneiro AJ, Andrade GN, Becker RS, Azevedo LB. Teste tuberculínico: diluição padronizada do PPD Rt 23 no Brasil. J Pneumol. 1986;12:21-7.

19. Brasil. Ministério da Saúde. Secretaria de Vigilância em Saúde. Departamento de Vigilância das Doenças Transmissíveis. Técnicas de aplicação e leitura da prova tuberculínica. Brasília: Ministério da Saúde; 2014. [cited 2020 Jan 7]. Available from: http://bvsms.saude.gov.br/bvs/publicacoes/ tecnicas_aplicacao_leitura_prova_tuberculinica.pdf 
20. Akolo C, Bada F, Okpokoro E, Nwanne O, Iziduh S, Usoroh E, et al. Debunking the myths perpetuating low implementation of isoniazid preventive therapy amongst human immunodeficiency virus-infected persons. World J Virol. 2015;4:105-12.

21. Brasil. Ministério da Saúde. Secretaria de Vigilância em Saúde. Brasil livre da tuberculose: evolução dos cenários epidemiológicos e operacionais da doença. Bol Epidemiol. 2019;50:1-18. [cited 2020 Jan 7]. Available from: http://portalarquivos2.saude.gov.br/images/pdf/2019/ marco/22/2019-009.pdf

22. Brasil. Ministério da Saúde. Secretaria de Vigilância em Saúde. Departamento de Vigilância das Doenças Transmissíveis. Manual de recomendações para o controle da tuberculose no Brasil. $2^{\mathrm{a}}$ ed. atual. Brasilia: Ministério da Saúde; 2019. [cited 2020 Jan 7]. Available from: http://bvsms.saude.gov.br/bvs/ publicacoes/manual_recomendacoes_controle_tuberculose_ brasil_2_ed.pdf

23. Siqueira KZ, Mendonça SA, Penedo CC. Indicação da prova tuberculínica e infecção latente da tuberculose em HIVpositivos, município de Blumenau, Estado de Santa Catarina, Brasil, 2004-2009. Epidemiol Serv Saude. 2012;21:635-44.

24. Lester R, Hamilton R, Charalambous S, Dwadwa T, Chandler C, Churchyard GJ, et al. Barriers to implementation of isoniazid preventive therapy in HIV clinics: a qualitative study. AIDS. 2010; 24 Suppl 5:S45-8.

25. Sociedade Brasileira de Medicina Tropical. Brasil está há mais de um ano sem conseguir comprar testes para diagnosticar tuberculose latente. [cited 2020 Jan 7]. Available from: http://www.sbmt. org.br/portal/brasil-esta-ha-mais-de-um-ano-sem-conseguircomprar-testes-para-diagnosticar-tuberculose-latente/

26. Tebruegge M, Bogyi M, Soriano-Arandes A, Kampmann B Shortage of purified protein derivative for tuberculosis testing. Lancet. 2014;384:2026.

27. Centers for Disease Control and Prevention. Nationwide shortage of tuberculin skin test antigens: CDC recommendations for patient care and public health practice. MMWR Morb Mortal Wkly Rep. 2019;68:552-3.

28. Little KM, Khundi M, Barnes GL, Ngwira LG, Nkhoma A, Makombe S, et al. Predictors of isoniazid preventive therapy completion among adults newly diagnosed with HIV in rural Malawi. Int J Tuberc Lung Dis. 2018;22:371-7.

29. Ayele HT, van Mourik MS, Bonten MJ. Predictors of adherence to isoniazid preventive therapy in people living with HIV in Ethiopia. Int J Tuberc Lung Dis. 2016;20:1342-7.
30. Saraceni V, Pacheco AG, Golub JE, Vellozo V, Rei BS, Cavalcante $\mathrm{SC}$, et al. Physician adherence to guidelines for tuberculosis and HIV care in Rio de Janeiro, Brazil. Braz J Infect Dis. 2011;15:249-52.

31. Trajman A, Long R, Zylberberg D, Dion M, Al-Otaibi B, Menzies D. Factors associated with treatment adherence in a randomised trial of latent tuberculosis infection treatment. Int $\mathbf{J}$ Tuberc Lung Dis. 2010;14:551-9.

32. Santos DT, Garcia MC, Costa AA, Pieri FM, Meier DA, Albanese SP, et al. Infecção latente por tuberculose entre pessoas com HIV/AIDS, fatores associados e progressão para doença ativa em município no Sul do Brasil. Cad Saude Publica. 2017;33:e00050916.

33. Thindwa D, MacPherson P, Choko AT, Khundi M, Sambakunsi R, Ngwira LG, et al. Completion of isoniazid preventive therapy among human immunodeficiency virus positive adults in urban Malawi. Int J Tuberc Lung Dis. 2018;22:273-9.

34. Machado Jr A, Finkmoore B, Emodi K, Takenami I, Barbosa T, Tavares M, et al. Risk factors for failure to complete a course of latent tuberculosis infection treatment in Salvador, Brazil. Int J Tuberc Lung Dis. 2009;13:719-25.

35. Alsdurf H, Hill PC, Matteelli A, Getahun H, Menzies D. The cascade of care in diagnosis and treatment of latent tuberculosis infection: a systematic review and meta-analysis. Lancet Infect Dis. 2016;16:1269-78.

36. Nsengiyumva N, Mappin-Kasirer B, Oxlade O, Bastos M, Trajman A, Falzon D, et al. Evaluating the potential costs and impact of digital health technologies for tuberculosis treatment support. Eur Respir J. 2018;52:1801363.

37. Daher A, Pitta L, Santos T, Barreira D, Pinto D. Using a single tablet daily to treat latent tuberculosis infection in Brazil: bioequivalence of two different isoniazid formulations (300 mg and $100 \mathrm{mg}$ ) demonstrated by a sensitive and rapid high-performance liquid chromatography-tandem mass spectrometry method in a randomised, crossover study. Mem Inst Oswaldo Cruz. 2015; 110:543-50.

38. Vidal JS, Silva MT, Sanchez MN. Rifapentine for latent tuberculosis infection treatment in the general population and human immunodeficiency virus-positive patients: summary of evidence. Rev Soc Bras Med Trop. 2015;48:507-13.

39. Kussen GM, Dalla-Costa LM, Rossoni A, Raboni SM. Interferongamma release assay versus tuberculin skin test for latent tuberculosis infection among HIV patients in Brazil. Braz $\mathrm{J}$ Infect Dis. 2016;20:69-75. 